\title{
DNA methylation in the pathogenesis of polycystic ovary syndrome
}

\author{
Edgar Ricardo Vázquez-Martínez¹, Yadira Inés Gómez-Viais , Elizabeth García-Gómez², \\ Christian Reyes-Mayoral ${ }^{3}$, Enrique Reyes-Muñoz ${ }^{4}$, Ignacio Camacho-Arroyo ${ }^{1}$ and Marco Cerbón ${ }^{1}$ \\ ${ }^{1}$ Unidad de Investigación en Reproducción Humana, Instituto Nacional de Perinatología-Facultad de Química, \\ Universidad Nacional Autónoma de México, Ciudad de México, México, ${ }^{2}$ Unidad de Investigación en \\ Reproducción Humana, Consejo Nacional de Ciencia y Tecnología (CONACyT)-Instituto Nacional de Perinatología, \\ Ciudad de México, México, ${ }^{3}$ Subdirección de Reproducción Humana, Instituto Nacional de Perinatología 'Isidro \\ Espinosa de los Reyes', Ciudad de México, México and ${ }^{4}$ Coordinación de Endocrinología Ginecológica y Perinatal, \\ Instituto Nacional de Perinatología 'Isidro Espinosa de los Reyes', Ciudad de México, México
}

Correspondence should be addressed to E R Vázquez-Martínez; Email: vamer@comunidad.unam.mx

\begin{abstract}
Polycystic ovary syndrome (PCOS) is the leading endocrine and metabolic disorder in premenopausal women characterized by hyperandrogenism and abnormal development of ovarian follicles. To date, the PCOS etiology remains unclear and has been related to insulin resistance, obesity, type 2 diabetes mellitus, cardiovascular disease and infertility, among other morbidities. Substantial evidence illustrates the impact of genetic, intrauterine and environmental factors on the PCOS etiology. Lately, epigenetic factors have garnered considerable attention in the pathogenesis of PCOS considering that changes in the content of DNA methylation, histone acetylation and noncoding RNAs have been reported in various tissues of women with this disease. DNA methylation is changed in the peripheral and umbilical cord blood, as well as in ovarian and adipose tissue of women with PCOS, suggesting the involvement of this epigenetic modification in the pathogenesis of the disease. Perhaps, these defects in DNA methylation promote the deregulation of genes involved in inflammation, hormone synthesis and signaling and glucose and lipid metabolism. Research on the role of DNA methylation in the pathogenesis of PCOS is just beginning, and several issues await investigation. This review aims to provide an overview of current research focused on DNA methylation and PCOS, as well as discuss the perspectives regarding this topic.

Reproduction (2019) 158 R27-R40
\end{abstract}

\section{Introduction}

Polycystic ovary syndrome (PCOS) is an endocrine and metabolic dysfunction characterized by hyperandrogenism and incomplete development of ovarian follicles that result in an anovulatory state (Dumesic \& Richards 2013, Trikudanathan 2015, Patel 2018). Alteration of the hypothalamic-pituitary-ovarian (HPO) axis is one major dysfunction observed in PCOS; this modification is because of an increase in the pulse frequency release of the gonadotropin-releasing hormone $(\mathrm{GnRH})$ from the hypothalamus, which, in turn, favors the synthesis and secretion of luteinizing hormone (LH) instead of follicle-stimulating hormone (FSH) by the pituitary gland. An elevation in serum levels of $\mathrm{LH}$ results in a high $\mathrm{LH} / \mathrm{FSH}$ ratio (higher than $2: 1$ ) that promotes androgen production in the ovarian theca cells (Trikudanathan 2015).

Remarkably, exposure to elevated androgens early in life, such as in women with congenital adrenal hyperplasia and prenatally androgenized animals, correlates with a decline in the negative feedback effect of estradiol and progesterone in the GnRH-mediated release of $\mathrm{LH}$, which is a typical characteristic in women with PCOS (Blank et al. 2006). A study recently proposed that prenatal exposure to androgens results in aberrant fetal programming in $\mathrm{GnRH}$ neurons that impairs their response to the steroid hormones negative feedback in mice (Silva et al. 2018).

Substantial evidence demonstrates that fetal programming with prenatal testosterone treatment results in a phenotype similar to PCOS during adulthood in models of sheep and monkeys (Padmanabhan \& Veiga-Lopez 2013, Rae et al. 2013, Abbott et al. 2016, Ramaswamy et al. 2016). In addition, prenatal exposure to elevated levels of anti-Müllerian hormone (elevated in pregnant women with PCOS) in pregnant mice programs female offspring to develop a PCOS phenotype during adulthood; however, this functional correlation has not been established in humans (Tata et al. 2018). 
Anovulation in women with PCOS is accompanied by menstrual dysfunction such as oligomenorrhea (menstrual periods occurring >35 days apart) or amenorrhea (absence of menstruation for, at least, 3 months), hyperandrogenism (evidenced by hirsutism, acne and alopecia), infertility and metabolic dysfunctions (Trikudanathan 2015, McCartney \& Marshall 2016). Recently, the updated diagnosis criteria and the international guidelines for the assessment and management of women with PCOS have been published (Neven et al. 2018, Teede et al. 2018).

Although PCOS is one of the leading endocrine and metabolic disorders in premenopausal women (range: 6-20\% worldwide), its etiology remains unclear to date (Teede et al. 2010, Goodarzi et al. 2011, Barber et al. 2015, Escobar-Morreale 2018a). PCOS is a chronic disease that directly affects the quality of life of reproductive age women as it is related to insulin resistance (60-70\% of cases), obesity, type 2 diabetes mellitus, cardiovascular disease and mood disorders (primarily depression), among others morbidities and is the leading cause of anovulatory infertility (Brassard et al. 2008, Teede et al. 2010, Sirmans \& Pate 2013, Reyes-Muñoz et al. 2016). The ovary is not the only affected tissue in the disease, as women with PCOS also exhibit adipose tissue dysfunction (Cortón et al. 2007, Thessaloniki ESHRE/ASRM-Sponsored PCOS Consensus Workshop Group 2008, Martínez-García et al. 2013, Montes-Nieto et al. 2013), insulin resistance in the skeletal muscle (Silva Dantas et al. 2013), elevated serum levels of inflammatory markers (Orio et al. 2005, Diamanti-Kandarakis et al. 2006a, Escobar-Morreale et al. 2011) and endometrial alterations (Piltonen 2016). Several studies have demonstrated the impact of genetic and environmental factors on the PCOS etiology (Abbott et al. 2005, Diamanti-Kandarakis et al. 2006b, Azziz et al. 2016, Mykhalchenko et al. 2017). Lately, epigenetic factors have garnered considerable attention in the study of the PCOS pathogenesis, considering that intrauterine and environmental insults, as well as lifestyle factors, might predispose to the disease development (EscobarMorreale 2018b, Patel 2018, Smyka et al. 2018, Tata et al. 2018). Some studies have revealed alterations in the content of miRNAs and long noncoding RNAs in tissues affected by PCOS (Sørensen et al. 2016, Concha et al. 2017, Liu et al. 2017, Sagvekar et al. 2018). In addition, other studies have indicated that modifications in histone acetylation could be involved in the acquisition of the PCOS phenotype (Nelson-DeGrave et al. 2004, Wood et al. 2005, Qu et al. 2012). In particular, DNA methylation is altered in the peripheral and umbilical cord blood, as well as in ovarian, adipose tissue and skeletal muscle of women with PCOS (Table 1), suggesting the involvement of DNA methylation in the PCOS pathogenesis as evidenced in the functions probably altered by this epigenetic modification (Fig. 1) and because of its participation in the regulation of gene expression and chromatin structure (Andersen \& Tost 2018). However, further investigation is warranted to establish the functional role of DNA methylation in patients with PCOS because of a lack of cause and effect studies. Hence, this review aims to provide an overview of current research focused on DNA methylation and PCOS, as well as discuss the perspectives regarding this topic.

\section{DNA methylation in PCOS}

DNA methylation is referred as an enzymatic reaction consisting of the addition of a methyl group generally at the carbon in the $5^{\prime}$ position of the pyrimidine ring of a cytosine followed by a guanine, called CpG dinucleotides (Illingworth et al. 2008). In addition, DNA methylation is involved in essential processes such as transcriptional regulation, $\mathrm{X}$ chromosome inactivation, imprinting, gametogenesis, development and differentiation, among others (Senner 2011). Alterations in DNA methylation are related to the pathogenesis of several diseases such as type 2 diabetes mellitus, neurodegenerative diseases, cardiovascular disease and cancer (Berson et al. 2018, Nebbioso et al. 2018, Rosa-Garrido et al. 2018, Zhou et al. 2018).

The interest in the role of DNA methylation in the PCOS pathogenesis began, at least, 10 years ago; however, a growing body of evidence reveals that women with PCOS have an altered epigenetic program due, in part, to this covalent modification (Fig. 1 and Table 1). In addition, alterations in DNA methylation have been noted in the peripheral and umbilical cord blood, suggesting a correlation between the PCOS phenotype and epigenetic changes in cells from systemic and fetal circulation. Remarkably, changes in DNA methylation have also been reported in tissues affected in the disease, including the ovary, adipose tissue and skeletal muscle (Table 1). Table 1 summarizes the studies that report DNA methylation changes related to PCOS, which includes observed changes in the gene expression, ontology terms obtained with the g:Profiler software (Reimand et al. 2016), and correlations reported between DNA methylation and clinical or functional findings observed in PCOS. Moreover, recent studies have highlighted the plasticity of DNA methylation observed across age and through therapeutic intervention in animal models and women with PCOS, which, in turn, has been related to phenotypical changes in the tissues affected by the disease (Xu et al. 2011, Cui et al. 2018, Kokosar et al. 2018). The fact that DNA methylation, gene expression and the corresponding phenotype can be modified opens the possibility of therapeutic interventions in PCOS. 
Table 1 Differentially methylated genes reported in tissues from patients with PCOS.

\begin{tabular}{|c|c|c|c|c|c|}
\hline Tissue & $\begin{array}{l}\text { Genes and their } \\
\text { associated changes in } \\
\text { DNA methylation in } \\
\text { patients with PCOS as } \\
\text { compared with healthy } \\
\text { women* }\end{array}$ & $\begin{array}{l}\text { Gene expression } \\
\text { changes } \\
\text { associated with } \\
\text { differential DNA } \\
\text { methylation }\end{array}$ & $\begin{array}{l}\text { Gene ontology and human } \\
\text { phenotype ontology terms } \\
\text { associated with differentially } \\
\text { methylated genes }\end{array}$ & $\begin{array}{l}\text { Clinical or functional } \\
\text { findings associated with } \\
\text { DNA methylation } \\
\text { changes }\end{array}$ & References \\
\hline $\begin{array}{l}\text { Peripheral } \\
\text { blood }\end{array}$ & $\begin{array}{l}\text { No change: SRD5A1, } \\
\text { CYP11A1, RPS4X and } \\
\text { KCN111 } \\
\text { Increased: LY6G6F, } \\
\text { KCTD21, ADCY9, } \\
\text { RABL2B, ZNF611, } \\
\text { VASH1, FST, LMNA and } \\
\text { PPARGC1A } \\
\text { Decreased: L-1, } \\
\text { TMSB15B, RPF1, DNA2, } \\
\text { EPHA8, LHCGR and } \\
\text { EPHX1 } \\
\text { Unspecified: JAML, } \\
\text { KBTBD12, SLC29A1, } \\
\text { GPR176, MYOZ2, PIGT, } \\
\text { C2CD4B, PCDHA7, } \\
\text { HMGA1 and PCDH18 }\end{array}$ & Not reported & $\begin{array}{l}\text { Response to gonadotropin and } \\
\text { cellular response to } \\
\text { gonadotropin stimulus }\end{array}$ & $\begin{array}{l}\text { Increased prolactin and } \\
\text { estradiol levels in } \\
\text { serum, increased free } \\
\text { androgen index, insulin } \\
\text { resistance, increased } \\
\text { triglyceride levels in } \\
\text { plasma and risk for } \\
\text { metabolic syndrome }\end{array}$ & $\begin{array}{l}\text { Sang et al. (2013, } \\
\text { 2014), Shen } \\
\text { et al. (2013), Ting } \\
\text { et al. (2013), } \\
\text { Wang et al. } \\
\text { (2014a), Li et al. } \\
\text { (2017), Sagvekar } \\
\text { et al. (2017), } \\
\text { Zhao et al. } \\
\text { (2017) }\end{array}$ \\
\hline $\begin{array}{l}\text { Umbilical cord } \\
\text { blood }\end{array}$ & $\begin{array}{l}\text { Increased: PRKN, PAX6, } \\
\text { B4GALT7, MEST, } \\
\text { CACNA2D2, RGMA and } \\
\text { PRDM10 } \\
\text { Decreased: ESR1, APP, } \\
\text { RBPMS LHCGR, } \\
\text { CASP10, SPHK1, } \\
\text { PCSK6, ARHGAP45 and } \\
\text { MIB2 }\end{array}$ & Not reported & 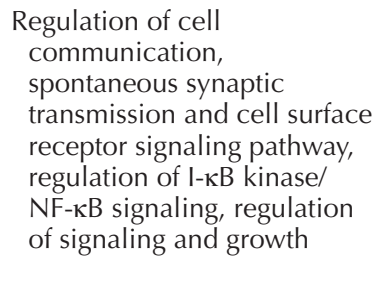 & Not reported & $\begin{array}{l}\text { Lambertini et al. } \\
(2017)\end{array}$ \\
\hline $\begin{array}{l}\text { Whole ovarian } \\
\text { tissue }\end{array}$ & $\begin{array}{l}\text { Increased: FBN1, NAV2, } \\
\text { PRDM1, RNF213, } \\
\text { SSBP2, TNIK, ZFAND3, } \\
\text { ZNF503, SLC2A8, } \\
\text { NRIP1, IGF2BP2, } \\
\text { CYP19A1, AMHR2, } \\
\text { SNURF, SUMO3, } \\
\text { PNMA6A, ADRA1D and } \\
\text { SCML1 } \\
\text { Decreased: C2CD6, } \\
\text { NROB1, INSR, AMH, } \\
\text { SPANXD, TUBA3E, } \\
\text { FAM47B, MAB21L1 and } \\
\text { RBM3 }\end{array}$ & $\begin{array}{l}\text { Increased: FBN1, } \\
\text { NAV2, RNF213, } \\
\text { TNIK and } \\
\text { ZFAND3 } \\
\text { Decreased: } \\
\text { PRDM1, SSBP2, } \\
\text { ZNF503 and } \\
\text { CYP19A1 } \\
\text { Increased: C2CD6 } \\
\text { and NROB1 }\end{array}$ & $\begin{array}{l}\text { Development of primary } \\
\text { sexual characteristics (female } \\
\text { gonad development), } \\
\text { reproductive system } \\
\text { development and } \\
\text { Developmental process } \\
\text { involved in reproduction } \\
\text { (female sex differentiation) }\end{array}$ & $\begin{array}{l}\text { Reduced aromatase } \\
\text { activity }\end{array}$ & $\begin{array}{l}\text { Yu et al. (2013), } \\
\text { Wang et al. } \\
\text { (2014b), Yu et al. } \\
\text { (2015) }\end{array}$ \\
\hline Granulosa cells & $\begin{array}{l}\text { No change: HDAC3, } \\
\text { SERPINE1, SPP1, } \\
\text { ANGPTL4, CYP17A1, } \\
\text { PEX3, DIRAS3, PTX3 } \\
\text { and SLC12A8 } \\
\text { Increased: MATN4, } \\
\text { DLGAP2, CDH13, } \\
\text { GAREM2, GSC, } \\
\text { ANKRD34C, ATP8B2 } \\
\text { and PPARG } \\
\text { Decreased: L-1, LHCGR, } \\
\text { SMG6, CCR5, LHB, } \\
\text { NTN1, ARFGAP1, } \\
\text { MDGA1, NCOR1, YAP1, } \\
\text { CD9, NR4A1, EDN2, } \\
\text { BNIP3 and LIF }\end{array}$ & $\begin{array}{l}\text { Increased: } \\
\text { LHCGR, } \\
\text { NCOR1, YAP1, } \\
\text { CD9, NR4A1, } \\
\text { EDN2, LIF and } \\
\text { BNIP3 }\end{array}$ & $\begin{array}{l}\text { Tube development, hormone- } \\
\text { mediated signaling pathway, } \\
\text { response to organic } \\
\text { substance and cellular } \\
\text { response to low-density } \\
\text { lipoprotein particle stimulus }\end{array}$ & $\begin{array}{l}\text { Hyperandrogenism } \\
\text { (evidenced by the } \\
\text { increase in the free } \\
\text { androgen index from } \\
\text { follicular fluid) }\end{array}$ & $\begin{array}{l}\text { Qu et al. (2012), } \\
\text { Wang et al. } \\
\text { (2014a), Xu et al. } \\
\text { (2016), Jiang } \\
\text { et al. (2017), } \\
\text { Sagvekar et al. } \\
\text { (2017) }\end{array}$ \\
\hline
\end{tabular}


Table 1 Continued.

\begin{tabular}{|c|c|c|c|c|c|}
\hline Tissue & $\begin{array}{l}\text { Genes and their } \\
\text { associated changes in } \\
\text { DNA methylation in } \\
\text { patients with PCOS as } \\
\text { compared with healthy } \\
\text { women* }\end{array}$ & $\begin{array}{l}\text { Gene expression } \\
\text { changes } \\
\text { associated with } \\
\text { differential DNA } \\
\text { methylation }\end{array}$ & $\begin{array}{l}\text { Gene ontology and human } \\
\text { phenotype ontology terms } \\
\text { associated with differentially } \\
\text { methylated genes }{ }^{\#}\end{array}$ & $\begin{array}{l}\text { Clinical or functional } \\
\text { findings associated with } \\
\text { DNA methylation } \\
\text { changes }\end{array}$ & References \\
\hline \multirow[t]{2}{*}{$\begin{array}{l}\text { Subcutaneous } \\
\text { adipose tissue }\end{array}$} & $\begin{array}{l}\text { Increased: ZZEF1, TPT1, } \\
\text { STUB1, DMAP1, } \\
\text { RAB5B, PPARG, SVEP1, } \\
\text { SAV1, RORA, RAB6A } \\
\text { and CNST }\end{array}$ & $\begin{array}{l}\text { Increased: } \\
\text { STUB1, RAB5B, } \\
\text { SAV1 and } \\
\text { RAB6A } \\
\text { Decreased: } \\
\text { ZZEF1, TPT1, } \\
\text { DMAP1, } \\
\text { PPARG, SVEP1, } \\
\text { RORA and } \\
\text { CNST }\end{array}$ & Oligomenorrhea & $\begin{array}{l}\text { Increased testosterone } \\
\text { levels in circulation }\end{array}$ & $\begin{array}{l}\text { Kokosar et al. } \\
(2016)\end{array}$ \\
\hline & $\begin{array}{l}\text { Decreased: PUM1, } \\
\text { DIP2C, SNX8, SRGAP3, } \\
\text { ZFHX3, OR52W1 and } \\
\text { BBX }\end{array}$ & $\begin{array}{l}\text { Increased: } \\
\text { OR52W1 } \\
\text { Decreased: } \\
\text { PUM1, DIP2C, } \\
\text { SNX8, SRGAP3, } \\
\text { ZFHX3 and BBX }\end{array}$ & & & \\
\hline \multirow[t]{2}{*}{ Skeletal muscle } & $\begin{array}{l}\text { Increased: CST3, SPRTN, } \\
\text { COL1A1, SCMH1, VAT1, } \\
\text { CSPP1, ERP29, ADK and } \\
\text { KLF10 }\end{array}$ & $\begin{array}{l}\text { Increased: } \\
\text { SPRTN, SCMH1, } \\
\text { CSPP1, ADK } \\
\text { and KLF10 } \\
\text { Decreased: CST3, } \\
\text { COL1A1, VAT1 } \\
\text { and ERP29 }\end{array}$ & $\begin{array}{l}\text { Rhythmic process (regulation } \\
\text { of circadian rhythms) }\end{array}$ & Not reported & $\begin{array}{l}\text { Nilsson et al. } \\
(2018)\end{array}$ \\
\hline & $\begin{array}{c}\text { Decreased: HEATR3, HIV, } \\
\text { MAP2K6 and FOXO3 }\end{array}$ & $\begin{array}{l}\text { Increased: } \\
\text { HEATR3, HIV, } \\
\text { MAP } 2 \text { K6 and } \\
\text { FOXO3 }\end{array}$ & & & \\
\hline
\end{tabular}

*The top 10 genes with the most significant changes in DNA methylation were included when considering genome-wide DNA methylation studies, as well as those related with the pathogenesis of the disease. Only studies assessing DNA methylation levels in specific loci were included in the list of genes without changes in DNA methylation; ${ }^{*}$ obtained by functional enrichment analysis of the differentially methylated genes included in this table using the web server g:Profiler and considering a corrected $P$ value $<0.05$ (Reimand et al. 2016).

\section{DNA methylation in the peripheral and cord blood from women with PCOS}

The first study reporting DNA methylation levels in women with PCOS was reported in 2010; the study obtained global levels of methylated DNA from the peripheral blood that were assessed by ELISA and found no significant differences between PCOS women and controls (Xu et al. 2010). These findings raised the question of whether changes in DNA methylation were specific to the genomic region and tissue in women with PCOS; however, technical limitations, such as small sample size, could not be eliminated to elucidate these results. Conversely, a decline in the DNA methylation levels of a CpG located at the $5^{\prime}$-untranslated region of long interspersed nucleotide element-1 (L-1) correlated with a global hypomethylated state of the genome in the peripheral blood of women with PCOS compared with controls, as L-1 is a well-known marker for global DNA methylation (Sagvekar et al. 2017).

After that, studies based on next-generation sequencing were conducted to assess genome-wide DNA methylation levels in the peripheral blood of women with PCOS, and numerous differentially methylated genes were found when compared with women without the disease. In particular, a total of 40 differentially methylated genes were found between PCOS women and controls using the genome-wide methylated DNA immunoprecipitation (meDIP) analysis, and most detected genes correlated with cancer, immune response, transcription regulation and metabolism (Shen et al. 2013). In addition, Shen et al. (2013) detected 79 differentially methylated genes when comparing PCOS women with insulin resistance and those without insulin resistance, suggesting that insulin resistance affects the phenotype of women with PCOS, perhaps, via the CEBPB gene, as altered DNA methylation of this gene correlated with a deregulation of several genes involved in the modulation of the inflammatory response and metabolism. Remarkably, $C E B P B$ encodes a transcription factor that participates in the ovarian follicle development and insulin signaling, both altered in women with PCOS (Yamamoto et al. 2002, Huang et al. 2007). Another study reported 52 differentially methylated CpGs between women with PCOS and controls using the bisulfite-based genomewide DNA methylation analysis (Li et al. 2017). In this study, different genes with altered DNA methylation were identified in comparison with Shen et al. (2013), 


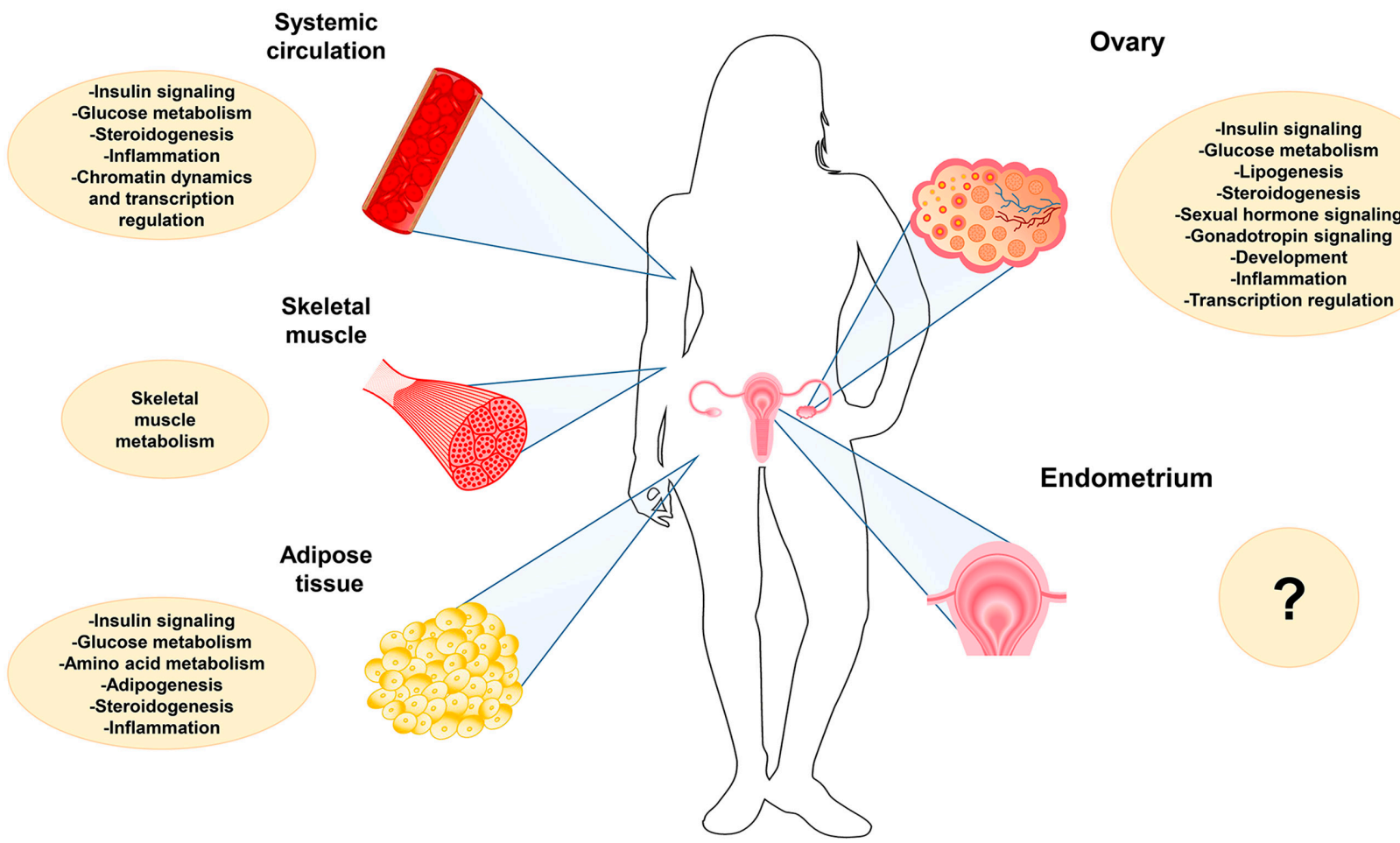

Figure 1 Functions probably related to DNA methylation in different tissues of patients with PCOS.

perhaps, because of differences in the technique used (the meDIP assay assesses relative levels of DNA methylation in genome fragments $<200 \mathrm{bp}$, whereas the techniques based on the conversion with bisulfite, detect changes in DNA methylation in a specific cytosine), sample size, ethnicity and the heterogeneous phenotype of PCOS women; however, genes identified with differential methylation also correlated with inflammation and metabolism (Li et al. 2017). Remarkably, Li et al. (2017) found a correlation between levels of DNA methylation in specific CpG sites and altered clinical variables in women with PCOS, such as serum levels of estradiol and prolactin, perhaps, because of the HPO axis dysfunction.

Together with the genome-wide DNA methylation studies conducted in the peripheral blood of patients with PCOS, studies focusing on the analysis of the DNA methylation content in specific genes have been conducted. In particular, an elevation of DNA methylation has been observed in the promoter of FST (which encodes follistatin), LMNA (encodes Lamin A/C) and PPARGC1A (encodes the peroxisome proliferatoractivated receptor gamma coactivator 1- 1 ), while reduced levels of this epigenetic mark have been reported in the promoter of the LHCGR gene (encodes the $\mathrm{LH}$ receptor) and $E P H X 1$ gene (encodes epoxide hydrolase 1) in women with PCOS compared with controls (Sang et al. 2013, 2014, Ting et al. 2013, Wang et al. 2014a, Zhao et al. 2017). These alterations in DNA methylation correlated with various molecular pathways and physiological processes that are dysregulated in
PCOS such as follicular development (Eldar-Geva et al. 2001), infertility (Hai et al. 2015), steroidogenesis (Korhonen et al. 2003), glucose metabolism and insulin signaling (Vandenbeek et al. 2018). In addition, DNA methylation defects in PPARGC1A have been related to insulin resistance and high serum androgen levels in women with PCOS, as well as with a decline in the mitochondrial DNA content, a well-known marker of metabolic disease when reduced in the peripheral blood (Zhao et al. 2017). Furthermore, Lamin A/C, which plays a pivotal role in chromatin dynamics and transcriptional programming during development, should affect the transcriptional program of several genes; thus, future studies should address this interesting issue (Solovei et al. 2013).

Intrauterine programming has been proposed as one of the plausible mechanisms that cause PCOS, as evidenced by the high heritability of the disease and animal models demonstrating that prenatal exposure to high levels of androgens or $\mathrm{AMH}$ results in the acquisition of the PCOS phenotype in the offspring (Filippou \& Homburg 2017, Tata et al. 2018). To date, several studies have been conducted in prenatal androgenized sheep and monkeys in which a PCOS phenotype was observed during adulthood, which, in turn, has been related to DNA methylation changes in the case of monkeys (Manikkam et al. 2006, Abbott et al. 2008, 2017, Veiga-Lopez et al. 2008, 2012, Smith et al. 2009, Ortega et al. 2010, Xu et al. 2011, Padmanabhan et al. 2014, Puttabyatappa et al. 2018). Nevertheless, little 
evidence exists about epigenetic alterations that could be related to intrauterine programming of the offspring of patients with PCOS. In particular, a genome-wide DNA methylation study examined the umbilical cord blood from women with PCOS; 614 hypermethylated and 1066 hypomethylated CpGs were reported (associated with 323 hypermethylated genes and 595 hypomethylated genes, respectively) compared with women without the disease (Lambertini et al. 2017). Remarkably, most affected genes correlated with glucose and lipid metabolism, hormone-related functions, regulation of inflammation and processes affected in PCOS women, suggesting that intrauterine programming of the PCOS phenotype could be mediated, at least, in part, by DNA methylation (Shen et al. 2013, Lambertini et al. 2017, Li et al. 2017). These findings should be confirmed in larger cohorts and it would be of great interest to follow-up the female progeny to ascertain if they develop PCOS symptoms during the reproductive age.

The limitation of studies assessing DNA methylation (and other epigenetic marks) in the peripheral blood is the fact that the total DNA is isolated from different cell types with their DNA methylation profile, whose content and epigenetic signature vary depending on diverse factors. Thus, the DNA methylation profile obtained is the average of the methylation levels in each cell type and should be deconvoluted to ascertain the epigenetic status of a specific cell type (Titus et al. 2017). In addition, the DNA methylation analysis of the peripheral blood does not necessarily reflect the status of specific organs or tissues affected by the disease. However, Li et al. (2017) reported that alterations in DNA methylation profiles of the peripheral blood from women with PCOS corroborate those obtained from the ovary tissue, indicating that certain alterations in DNA methylation should be inferred from the peripheral blood, which is of great significance, as this would avoid the invasive procedure of the biopsy. Remarkably, all studies examining the peripheral blood indicate that the PCOS phenotype correlates with an alteration in the DNA methylation content of genes involved in the inflammatory response, glucose and lipid metabolism and hormone signaling, which, in turn, is associated with the presence of a systemic dysfunction characterized by chronic inflammation accompanied by hyperandrogenism and insulin resistance (Shorakae et al. 2018). Besides, these alterations in the DNA methylation program could be acquired during fetal development as proposed by Lambertini et al. (2017).

\section{DNA methylation in the ovarian tissue and granulosa cells from women with PCOS}

Ovulation is one of the primary processes affected by PCOS as alterations in the HPO axis (that increase serum androgens) induce follicular atresia and follicular maturation arrest, which, in turn, cause oligo-ovulation or anovulation (Dumesic et al. 2015). In particular, ovarian follicular arrest correlates with a decline in $\mathrm{FSH}$ responsiveness of the ovarian tissue (Fauser \& Van Heusden 1997). In turn, an increase in $\mathrm{LH}$ levels overstimulates theca cells to secrete excessive androgens that impair follicular growth and maturation, a situation that is augmented when combined with the gonadotrophic effect of insulin, resulting in the accumulation of atresic or immature ovarian follicles that cause polycystic ovarian morphology (Nestler et al. 1998). These molecular and morphological changes in the ovarian tissue could be attributed to epigenetic alterations as proposed in animal models of PCOS. Predominantly, studies have reported that prenatal testosterone treatment in sheep results in an increase in the occurrence of persistent and growing follicles (contributing to the morphology of a PCO), luteal and antral follicles defects, a decline in primordial follicles and an altered ovarian protein content of $\mathrm{AMH}$, ovarian steroidogenic enzymes, matrix metalloproteases and proteins related to insulin pathway during adulthood (Manikkam et al. 2006, Veiga-Lopez et al. 2008, 2012, Smith et al. 2009, Ortega et al. 2010, Padmanabhan et al. 2014, Puttabyatappa et al. 2018). Remarkably, this fetal programming induced by prenatal testosterone correlates with defects in the expression of ovarian steroidogenic genes and miRNAs associated with insulin pathway in the ovaries of fetal ewes (Luense et al. 2011). Reportedly, a decline in DNA methylation levels of the promoter of Gata6 and Star steroidogenic genes occurs in theca cells of prenatal androgenized rats (Salehi Jahromi et al. 2018).

DHEA treatment in prepubertal female mice results in a phenotype similar to PCOS. Remarkably, a decline in the total content of DNA methylation and the expression of Dnmt 1 has been observed in oocytes from female mice treated with DHEA (Eini et al. 2017). Using a mice model of hyperinsulinemia and hyperandrogenism combined with single-cell technology, DNA methylation changes in single oocytes reportedly associated with several molecular functions such as transcriptional regulation, Notch signaling and cell division (Li et al. 2018). In addition, prenatal exposure to androgens in rats produces a phenotype similar to PCOS that arises during adulthood; this PCOS-like phenotype correlates with alterations in the content of DNA methylation in the ovarian tissue, especially in the promoters of genes involved in the development of reproductive organs and hormone-related processes. These findings indicate that ovarian alterations observed in PCOS can be programmed during development (Zhang et al. 2014).

The study of DNA methylation in the ovarian tissue of women with PCOS has been conducted using techniques that analyze either the whole genome or a specific locus. Some genome-wide DNA methylation studies have been conducted in the ovarian tissue of women 
with PCOS, which differ based on the specifically used technique (Wang et al. 2014b, Yu et al. 2015). In particular, variations in DNA methylation levels of genomic regions related to 342 genes were found in the ovarian tissue of women with PCOS compared with controls using meDIP coupled to microarray analysis (Yu et al. 2015). In this study, hypermethylated genomic regions in women with PCOS were preferably distributed on $\mathrm{CpG}$ island shores (genomic regions that are $1-2 \mathrm{~kb}$ from a CpG island) and promoters with high CpG content, whereas hypomethylated regions were found in gene bodies. Conversely, using the bisulfitebased genome-wide DNA methylation analysis, Wang et al. (2014b) reported that CpG islands and CpG island shores were hypomethylated in women with PCOS compared with controls. The differences between these two studies could be attributed to the small sample size analyzed in both studies, as well as to the heterogeneity of the disease. In addition, Wang et al. (2014b) reported a correlation between changes in DNA methylation and mRNA expression in 54 genes of 7929 differentially methylated CpGs, raising the question whether changes in DNA methylation observed in other regions of the genome correlate with the altered gene expression. In these studies, differentially methylated genes between the ovarian tissue from women with PCOS and controls correlated with hormone activity (including CYP19A1, $A M H$ and $A M H R 2$ genes that are markedly related to the PCOS pathogenesis), transcriptional regulation, inflammation, glucose metabolism and insulin signaling (Wang et al. 2014b, Yu et al. 2015). Using methylationspecific PCR, an increase in the methylation levels of CYP19A1 promoter was reported in the ovarian tissue of women with PCOS compared with controls, which correlated with a concomitant reduction in the mRNA and protein content, indicating a correlation between epigenetic alterations and an increase in androgen levels that results in the PCOS phenotype (Yu et al. 2013). CYP19A1 encodes aromatase that converts androgens into estrogens and is expressed in differentiated preovulatory granulosa cells and luteal cells (Stocco 2012). The aromatase activity is decreased in patients with PCOS, perhaps, by an increase of androgens in circulation and follicular fluid (Chen et al. 2015, Yang et al. 2015). Reportedly, prenatal testosterone treatment downregulates the expression of aromatase in granulosa cells from adult sheep (Padmanabhan et al. 2014), indicating that the increase in DNA methylation in CYP19A1 promoter observed in women with PCOS could be the result of the prenatal exposure to high levels of androgens.

Most studies focusing on DNA methylation and PCOS have been conducted in granulosa cells, which play a fundamental role in steroidogenesis and ovarian folliculogenesis and whose dysfunction correlates with the pathogenesis of the disease (Pellatt et al. 2007; Lan et al. 2015). Some studies have reported differences in the global content of DNA methylation in granulosa cells of women with PCOS compared with controls (Pruksananonda et al. 2016, Xu et al. 2016, Sagvekar et al. 2017, Pan et al. 2018). In particular, a global hypomethylated state of the genome in granulosa cells of women with PCOS (evidenced by a decline in the DNA methylation levels of L-1) correlated with the hormonal alterations of the disease (Sagvekar et al. 2017). A genome-wide study revealed that granulosa cells of PCOS women with obesity exhibit variations in the content of DNA methylation compared with PCOS women without obesity (5202 differentially methylated CpGs) and women without the disease (6936 differentially methylated CpGs), albeit the highest difference was observed between PCOS women without obesity and controls $(12,245$ differentially methylated CpGs), indicating that obesity affects not only the phenotype of women with PCOS but also their epigenetic program (Xu et al. 2016). However, no differences were observed in molecular functions related to the differentially methylated genes between the three groups, which correlated with the regulation of transcription and development. Although $\mathrm{Xu}$ et al. (2016) did not find differences in the global content of $5 \mathrm{hmC}$, changes in specific genomic regions must be assessed to eliminate the participation of this epigenetic mark in the PCOS pathogenesis.

In addition, alterations in DNA methylation have been reported in several genes associated with the ovary function and morphology in granulosa cells of women with PCOS, which, in turn, correlates with the response to gonadotropins, insulin signaling and steroidogenesis (Qu et al. 2012, Wang et al. 2014a, Jiang et al. 2017, Pan et al. 2018).

Decreased levels of DNA methylation in the LHCGR gene promoter and a concomitant increase in the gene expression have been reported in granulosa cells of women with PCOS compared with controls (Wang et al. 2014a). In addition, LHCGR variants have been related to PCOS in genome-wide association studies (GWAS), and its overexpression has been associated with a hypersensitivity to LH impulses in ovarian follicles, which would contribute to the PCOS pathogenesis (Shi et al. 2012, Mutharasan et al. 2013). Another study analyzing granulosa cells from patients with PCOS reported the increased expression of $\angle H C G R$, along with an upregulated activity of this receptor (Kanamarlapudi et al. 2016). These studies indicate that the reduction in DNA methylation of the LHCGR gene promoter should correlate with the overexpression of an active form of $\mathrm{LH}$ receptor in granulosa cells that, in turn, results in a hyper-response to gonadotrophins in the ovaries of women with PCOS.

Hyperandrogenism in women with PCOS has been related to a decline in DNA methylation levels of NCOR1 promoter and with an elevation in those of PPARG promoter in granulosa cells, which 
corresponded to a higher and lower gene expression, respectively, compared with PCOS women without hyperandrogenism (diagnosed according to the Rotterdam criteria) and women without the disease $(\mathrm{Qu}$ et al. 2012). PPARG encodes PPARG that regulates the ovarian function, whereas NCOR1 encodes a nuclear corepressor of PPARG that is essential in reproductive functions and hormonal signaling (Gao et al. 2006, Toth et al. 2007). Thus, Qu et al. (2012) demonstrated the correlation between androgen excess and PCOS epigenetic alterations, as alterations in DNA methylation and gene expression of the PPARG and NCOR1 genes in PCOS women with hyperandrogenism were replicated in in vitro and animal models. Remarkably, prenatal testosterone treatment induces the PPARG expression during fetal life in sheep ovaries, which correlates with the developmental programming of ovarian dysfunction observed in adult animals; however, no differences were reported in adult animals (Ortega et al. 2010). Further studies are warranted to investigate whether DNA methylation is involved in this fetal programming of increased PPARG expression mediated by the prenatal testosterone treatment. In addition, a study reported that PPARG agonists and insulin induce the expression of PPARG, STAR, INSR and IRS- 1 in human ovarian cells, indicating the interaction of insulin signaling and steroidogenesis (Seto-Young et al. 2007); this also highlights the therapeutic potential of PPARG agonists, as they enhance the ovarian insulin sensitivity and inhibit androgen production, which is altered in women with PCOS (Seto-Young et al. 2005). Hence, further studies should be assessed to investigate the effect of PPARG agonists on DNA methylation.

Yes-associated protein-1 (Yap1) regulates the proliferation of granulosa cells, and its hyperactivation by androgens inhibits ovulation in mice (Ji et al. 2017). Reportedly, several CpGs in the YAP1 gene promoter are hypomethylated in granulosa cells of women with PCOS compared with controls (along with an elevation in protein and mRNA levels), perhaps, because of high androgen levels, suggesting that YAP1 hyperactivation might be mediated by DNA methylation (Jiang et al. 2017).

In granulosa cells, alterations in promoter DNA methylation and gene expression levels have been reported in several genes that participate in the synthesis of lipids and steroids (CD9, BNIP3, EDN2, $N R 4 A 1$ and $L I F)$, indicating that epigenetic alterations could correlate with steroidogenesis and metabolic dysfunction observed in PCOS (Pan et al. 2018).

Further investigation with higher sample size and a more homogeneous population is warranted in the ovarian tissue of PCOS women to elucidate the regions in the genome that are differentially methylated in the disease. The use of single-cell technology coupled with next-generation sequencing should be applied to determine the alterations in the DNA methylation content of oocytes obtained from women with PCOS, which would exert a marked impact on assisted reproductive technology.

\section{DNA methylation in the adipose tissue and skeletal muscle from women with PCOS}

The presence of abdominal obesity and alterations in the adipose tissue in women with PCOS markedly correlates with insulin resistance, which, in turn, promotes the synthesis of androgens in the ovary that worsen metabolic dysfunctions (Delitala et al. 2017). Alterations in the morphology and function of the adipose tissue in women with PCOS have been described previously, including increased adipocyte size and reduced adiponectin expression and secretion (Mannerås-Holm et al. 2011). Reportedly, hyperinsulinemia promotes testosterone synthesis by inducing the activity of aldo-ketoreductase type 1C3 (that converts androstenedione to testosterone) in subcutaneous adipose tissue, contributing to elevated androgen levels in patients with PCOS (O'Reilly et al. 2015). Remarkably, prenatal androgen exposure in rhesus monkey induces modifications in DNA methylation levels in the visceral adipose tissue of infant and adult animals, establishing the impact of prenatal androgen exposure on intrauterine programming of the PCOS phenotype. Remarkably, a different set of genes were differentially methylated between infant and adult animals in this study, highlighting the plasticity of this epigenetic modification across age (Xu et al. 2011). These findings suggest that the DNA methylation profile observed in adults should not be the same presented in newborns destined to have adult PCOS, raising the question whether epigenetic alterations and the related increased adiposity are the consequence and not a fundamental feature of the disease.

Using a genome-wide approach, a study demonstrated that $440 \mathrm{CpG}$ are differentially methylated in the subcutaneous adipose tissue of women with PCOS compared with that of controls, and, notably, changes in DNA methylation in $33 \mathrm{CpG}$ sites corroborated changes in the gene expression (Kokosar et al. 2016). In this study, authors inferred the functional role of the variations in DNA methylation at the expression level in the adipose tissue of women with PCOS, which enabled them to construct a complete scenario of the correlations between epigenetic changes and phenotype variables observed in the disease, including hyperandrogenemia, insulin resistance and adipocyte size. In particular, genes that exhibited alterations in DNA methylation and mRNA expression levels are involved in inflammation, adipogenesis, metabolism of sex hormones and glucose and amino acid metabolism, pathways commonly affected in PCOS and adipose tissue dysfunction (Delitala et al. 2017, Escobar-Morreale 2018a). In addition, Kokosar et al. (2016) reported differentially methylated 
and expressed genes that were previously identified as candidate genes for PCOS and type 2 diabetes mellitus (RAB5B, PPARG and SVEP1), indicating their association with the disease at genetic and epigenetic levels.

Remarkably, low-frequency electrical stimulation acupuncture induces several changes in DNA methylation and mRNA levels in the adipose tissue of women with PCOS (Kokosar et al. 2018). In particular, a single bout of 45-min electroacupuncture promotes changes in the DNA methylation levels of 407 CpGs, which correlates with corresponding changes in the gene expression and glucose uptake in the whole body. This promising therapy induces muscle contractions by activating transcriptional and signaling programs similar to those activated during exercise, promoting the restoration of metabolic dysfunctions in women with PCOS (Stener-Victorin 2013, Benrick et al. 2017). These findings have been related to a partial restoration of DNA methylation content and gene expression levels previously associated with metabolic complications of PCOS, insulin resistance and alterations in adipogenesis and inflammation, highlighting the significance of lifestyle intervention in the management of PCOS (Kokosar et al. 2018). This study highlights the plasticity of DNA methylation, which can be modified by therapeutic intervention to reestablish the transcriptional program and restore the dysfunction observed in the adipose tissue of women with PCOS. Nevertheless, further studies are warranted to establish whether electroacupuncture therapy will maintain these epigenetic changes when applied regularly, as well as ascertain the duration of those changes. Furthermore, the participation of other epigenetic mechanisms must be investigated to decode the epigenetic program that arbitrates glucose uptake dependent on muscle contraction in women with PCOS.

In addition, further studies are needed to determine whether other therapies that focus on the metabolic improvement of women with PCOS (such as metformin, diet and physical activity) could modulate the content of DNA methylation in the adipose tissue of these women.

Insulin resistance in patients with PCOS correlates with defects in insulin signaling in the skeletal muscle, which, in turn, is considered a risk factor for type 2 diabetes mellitus (Dunaif et al. 2001, Li et al. 2002, Corbould et al. 2005, 2006, Skov et al. 2007). Only one recent study investigated DNA methylation in the skeletal muscle of women with PCOS and reported minor statistical differences in the levels of DNA methylation between women with PCOS and those without the disease. However, correlations between DNA methylation and gene expression were established in genes related to the regulation of circadian clock, skeletal muscle metabolism and skeletal muscle homeostasis (Nilsson et al. 2018). Nevertheless, more studies are needed to illustrate the functional role of DNA methylation in skeletal muscle insulin resistance.
Besides, it is imperative to study other epigenetic mechanisms that could be involved in the disease.

\section{Perspectives and conclusion}

Research on the role of DNA methylation in the PCOS pathogenesis has just begun, and although significant progress has been made, several issues merit investigation.

Nevertheless, genome-wide DNA methylation studies indicate that differentially methylated genes in various tissues affected by PCOS are related to inflammation, hormone-related processes and glucose and lipid metabolism. However, more studies with a higher sample size and a more homogeneous population are warranted to attain more consistent results. Extensive evidence has revealed the alteration of DNA methylation in the peripheral blood of women with PCOS; however, no information exists about DNA methylation profiles in specific populations of leucocytes. The study of DNA methylation in specific cell populations from the peripheral blood will provide the molecular basis of chronic inflammation observed in women with PCOS. Remarkably, a higher number of genes with altered content of DNA methylation are detected in specific tissues affected by PCOS than that in the peripheral blood, highlighting the significance of the study of DNA methylation in specific tissues affected by PCOS. In fact, the endometrium is an established tissue affected by PCOS, as several functional markers are deregulated in women with the disease, and although transcriptomic and proteomic studies have been performed, genomewide DNA methylation studies have not been addressed (Piltonen 2016, Amjadi et al. 2018; Fig. 1). In addition, the study of active DNA demethylation intermediates (such as 5-hydroxymethylcytosine) should assess the tissues affected by the disease via genome-wide or genespecific studies.

A study recently reported that metformin regulates the DNA methylation process by controlling the activity of S-adenosylhomocysteine hydrolase, an enzyme that hydrolyzes S-adenosylhomocysteine, which inhibits the activity of DNMTs (Zhong et al. 2017). However, to date, no study has evaluated the impact of metformin on DNA methylation levels in women with PCOS, which is of great significance as metformin is one of the main lines of treatment against PCOS.

Finally, there is a paucity of knowledge about the functional role of DNA methylation changes reported in women with PCOS, as most changes do not have an apparent impact in the gene expression. Thus, more studies must address the significance of DNA methylation changes in the gene expression and chromatin structure in PCOS animal models. Prenatal androgenized animals and next-generation sequencing technologies could elucidate fetal programming of PCOS such as those 
related to the onset of an epigenetic signature in the tissues affected by the disease. Furthermore, the advances in dCas9 technology will offer a more reliable tool to investigate the functional effects of specific changes in DNA methylation that result in a PCOS phenotype (Lei et al. 2017).

The alteration of DNA methylation in women with PCOS correlates with systemic and tissuespecific dysfunctions, which, in turn, are related to hyperandrogenism and insulin resistance; these defects in DNA methylation promote the deregulation of genes involved in inflammation, hormone-related processes and glucose and lipid metabolism. A growing body of evidence suggests that these alterations can be acquired during development, indicating a vital role in intrauterine programming. Nevertheless, more research is warranted to elucidate the role of DNA methylation in the PCOS pathogenesis; however, recent studies have provided crucial advances that raise the question about its participation in the development of this disease.

\section{Declaration of interest}

The authors declare that there is no conflict of interest that could be perceived as prejudicing the impartiality of this review.

\section{Funding}

This work was supported by the Fondo Sectorial de Investigación en Salud y Seguridad Social (FOSISS) from the Consejo Nacional de Ciencia y Tecnología (CONACyT; grant number 272682) and the Instituto Nacional de Perinatología 'Isidro Espinosa de los Reyes' (INPer; grant number 569, 212250 3000-20209-04-16). Y I G V was supported by a master's scholarship from the CONACYT (scholarship number 711002).

\section{References}

Abbott DH, Barnett DK, Bruns CM \& Dumesic DA 2005 Androgen excess fetal programming of female reproduction: a developmental aetiology for polycystic ovary syndrome? Human Reproduction Update $\mathbf{1 1}$ 357-374. (https://doi.org/10.1093/humupd/dmi013)

Abbott DH, Barnett DK, Levine JE, Padmanabhan V, Dumesic DA, Jacoris S \& Tarantal AF 2008 Endocrine antecedents of polycystic ovary syndrome in fetal and infant prenatally androgenized female rhesus monkeys. Biology of Reproduction 79 154-163. (https://doi. org/10.1095/biolreprod.108.067702)

Abbott DH, Levine JE \& Dumesic DA 2016 Translational insight into polycystic ovary syndrome (PCOS) from female monkeys with PCOSlike traits. Current Pharmaceutical Design 22 5625-5633. (https://doi.or g/10.2174/1381612822666160715133437)

Abbott DH, Rayome BH, Dumesic DA, Lewis KC, Edwards AK, Wallen K, Wilson ME, Appt SE \& Levine JE 2017 Clustering of PCOS-like traits in naturally hyperandrogenic female rhesus monkeys. Human Reproduction 32 923-936. (https://doi.org/10.1093/humrep/dex036)

Amjadi F, Mehdizadeh M, Ashrafi M, Nasrabadi D, Taleahmad S, Mirzaei M, Gupta V, Salekdeh GH \& Aflatoonian R 2018 Distinct changes in the proteome profile of endometrial tissues in polycystic ovary syndrome compared with healthy fertile women. Reproductive Biomedicine Online 37 184-200. (https://doi.org/10.1016/j.rbmo.2018.04.043)
Andersen GB \& Tost J 2018 A summary of the biological processes, diseaseassociated changes, and clinical applications of DNA methylation. Methods in Molecular Biology 1708 3-30. (https://doi.org/10.1007/9781-4939-7481-8_1)

Azziz R, Carmina E, Chen Z, Dunaif A, Laven JSE, Legro RS, Lizneva D, Natterson-Horowtiz B, Teede HJ \& Yildiz BO 2016 Polycystic ovary syndrome. Nature Reviews: Disease Primers 2 16057. (https://doi. org/10.1038/nrdp.2016.57)

Barber TM, Dimitriadis GK, Andreou A \& Franks S 2015 Polycystic ovary syndrome: insight into pathogenesis and a common association with insulin resistance. Clinical Medicine 15 s72-s76. (https://doi. org/10.7861/clinmedicine.15-6-s72)

Benrick A, Kokosar M, Hu M, Larsson M, Maliqueo M, Marcondes RR, Soligo M, Protto V, Jerlhag E, Sazonova A et al. 2017 Autonomic nervous system activation mediates the increase in whole-body glucose uptake in response to electroacupuncture. FASEB Journal 31 3288-3297. (https:// doi.org/10.1096/fj.201601381R)

Berson A, Nativio R, Berger SL \& Bonini NM 2018 Epigenetic regulation in neurodegenerative diseases. Trends in Neurosciences 41 587-598. (https://doi.org/10.1016/j.tins.2018.05.005)

Blank SK, McCartney CR \& Marshall JC 2006 The origins and sequelae of abnormal neuroendocrine function in polycystic ovary syndrome. Human Reproduction Update 12 351-361. (https://doi.org/10.1093/ humupd/dml017)

Brassard M, AinMelk Y \& Baillargeon JP 2008 Basic infertility including polycystic ovary syndrome. Medical Clinics of North America 92 1163-1192, xi. (https://doi.org/10.1016/j.mcna.2008.04.008)

Chen J, Shen S, Tan Y, Xia D, Xia Y, Cao Y, Wang W, Wu X, Wang H, Yi L et al. 2015 The correlation of aromatase activity and obesity in women with or without polycystic ovary syndrome. Journal of Ovarian Research 8 11. (https://doi.org/10.1186/s13048-015-0139-1)

Concha CF, Sir PT, Recabarren SE \& Pérez BF 2017 Epigenetics of polycystic ovary syndrome. Revista Medica de Chile 145 907-915. (https://doi. org/10.4067/s0034-98872017000700907)

Corbould A, Kim YB, Youngren JF, Pender C, Kahn BB, Lee A \& Dunaif A 2005 Insulin resistance in the skeletal muscle of women with PCOS involves intrinsic and acquired defects in insulin signaling. American Journal of Physiology: Endocrinology and Metabolism 288 E1047E1054. (https://doi.org/10.1152/ajpendo.00361.2004)

Corbould A, Zhao H, Mirzoeva S, Aird F \& Dunaif A 2006 Enhanced mitogenic signaling in skeletal muscle of women with polycystic ovary syndrome. Diabetes 55 751-759. (https://doi.org/10.2337/ diabetes.55.03.06.db05-0453)

Cortón M, Botella-Carretero JI, Benguría A, Villuendas G, Zaballos A, San Millán JL, Escobar-Morreale HF \& Peral B 2007 Differential gene expression profile in omental adipose tissue in women with polycystic ovary syndrome. Journal of Clinical Endocrinology and Metabolism 92 328-337. (https://doi.org/10.1210/jc.2006-1665)

Cui P, Ma T, Tamadon A, Han S, Li B, Chen Z, An X, Shao LR, Wang Y \& Feng Y 2018 Hypothalamic DNA methylation in rats with dihydrotestosterone-induced polycystic ovary syndrome: effects of low-frequency electro-acupuncture. Experimental Physiology 103 1618-1632. (https://doi.org/10.1113/EP087163)

Delitala AP, Capobianco G, Delitala G, Cherchi PL \& Dessole S 2017 Polycystic ovary syndrome, adipose tissue and metabolic syndrome. Archives of Gynecology and Obstetrics 296 405-419. (https://doi. org/10.1007/s00404-017-4429-2)

Diamanti-Kandarakis E, Alexandraki K, Piperi C, Protogerou A, Katsikis I, Paterakis T, Lekakis J \& Panidis D 2006a Inflammatory and endothelial markers in women with polycystic ovary syndrome. European Journal of Clinical Investigation 36 691-697. (https://doi.org/10.1111/j.13652362.2006.01712.x)

Diamanti-Kandarakis E, Kandarakis H \& Legro RS 2006b The role of genes and environment in the etiology of PCOS. Endocrine 30 19-26. (https:// doi.org/10.1385/ENDO:30:1:19)

Dumesic DA \& Richards JS 2013 Ontogeny of the ovary in polycystic ovary syndrome. Fertility and Sterility $10023-38$. (https://doi.org/10.1016/j. fertnstert.2013.02.011)

Dumesic DA, Oberfield SE, Stener-Victorin E, Marshall JC, Laven JS \& Legro RS 2015 Scientific statement on the diagnostic criteria, epidemiology, pathophysiology, and molecular genetics of polycystic ovary syndrome. Endocrine Reviews 36 487-525. (https://doi.org/10.1210/er.2015-1018) 
Dunaif A, Wu X, Lee A \& Diamanti-Kandarakis E 2001 Defects in insulin receptor signaling in vivo in the polycystic ovary syndrome (PCOS). American Journal of Physiology: Endocrinology and Metabolism 281 E392-E399. (https://doi.org/10.1152/ajpendo.2001.281.2.E392)

Eini F, Novin MG, Joharchi K, Hosseini A, Nazarian H, Piryaei A \& Bidadkosh A 2017 Intracytoplasmic oxidative stress reverses epigenetic modifications in polycystic ovary syndrome. Reproduction, Fertility, and Development 29 2313-2323. (https://doi.org/10.1071/RD16428)

Eldar-Geva T, Spitz IM, Groome NP, Margalioth EJ \& Homburg R 2001 Follistatin and activin A serum concentrations in obese and non-obese patients with polycystic ovary syndrome. Human Reproduction 16 2552-2556. (https://doi.org/10.1093/humrep/16.12.2552)

Escobar-Morreale HF 2018a Polycystic ovary syndrome: definition, aetiology, diagnosis and treatment. Nature Reviews: Endocrinology 14 270-284. (https://doi.org/10.1038/nrendo.2018.24)

Escobar-Morreale HF $2018 b$ Polycystic ovary syndrome: definition, aetiology, diagnosis and treatment. Nature Reviews: Endocrinology 14 270-284. (https://doi.org/10.1038/nrendo.2018.24)

Escobar-Morreale HF, Luque-Ramírez M \& González F 2011 Circulating inflammatory markers in polycystic ovary syndrome: a systematic review and metaanalysis. Fertility and Sterility 95 1048.e1-1058.e1. (https://doi. org/10.1016/j.fertnstert.2010.11.036)

Fauser BC \& Van Heusden AM 1997 Manipulation of human ovarian function: physiological concepts and clinical consequences. Endocrine Reviews 18 71-106. (https://doi.org/10.1210/edrv.18.1.0290)

Filippou P \& Homburg R 2017 is foetal hyperexposure to androgens a cause of PCOS? Human Reproduction Update 23 421-432. (https://doi. org/10.1093/humupd/dmx013)

Gao Z, He Q, Peng B, Chiao PJ \& Ye J 2006 Regulation of nuclear translocation of HDAC3 by IkappaBalpha is required for tumor necrosis factor inhibition of peroxisome proliferator-activated receptor gamma function. Journal of Biological Chemistry 281 4540-4547. (https://doi. org/10.1074/jbc.M507784200)

Goodarzi MO, Dumesic DA, Chazenbalk G \& Azziz R 2011 Polycystic ovary syndrome: etiology, pathogenesis and diagnosis. Nature Reviews: Endocrinology 7 219-231. (https://doi.org/10.1038/nrendo.2010.217)

Hai L, McGee SR, Rabideau AC, Paquet M \& Narayan P 2015 Infertility in female mice with a gain-of-function mutation in the luteinizing hormone receptor is due to irregular estrous cyclicity, anovulation, hormonal alterations, and polycystic ovaries. Biology of Reproduction 9316. (https://doi.org/10.1095/biolreprod.115.129072)

Huang AM, Rudelius M, Sharan S, McAllister JM, Raffeld M, Christenson LK \& Sterneck E 2007 The Cebpd (C/EBPdelta) gene is induced by luteinizing hormones in ovarian theca and interstitial cells but is not essential for mouse ovary function. PLOS ONE 2 e1334. (https://doi.org/10.1371/ journal.pone.0001334)

Illingworth R, Kerr A, Desousa D, Jørgensen H, Ellis P, Stalker J, Jackson D, Clee C, Plumb R, Rogers J et al. 2008 A novel CpG island set identifies tissue-specific methylation at developmental gene loci. PLoS Biology $\mathbf{6}$ e22. (https://doi.org/10.1371/journal.pbio.0060022)

Ji SY, Liu XM, Li BT, Zhang YL, Liu HB, Zhang YC, Chen ZJ, Liu J \& Fan HY 2017 The polycystic ovary syndrome-associated gene Yap1 is regulated by gonadotropins and sex steroid hormones in hyperandrogenisminduced oligo-ovulation in mouse. Molecular Human Reproduction 23 698-707. (https://doi.org/10.1093/molehr/gax046)

Jiang LL, Xie JK, Cui JQ, Wei D, Yin BL, Zhang YN, Chen YH, Han X, Wang Q \& Zhang CL 2017 Promoter methylation of yes-associated protein (YAP1) gene in polycystic ovary syndrome. Medicine 96 e5768. (https://doi.org/10.1097/MD.0000000000005768)

Kanamarlapudi V, Gordon UD \& López Bernal A 2016 Luteinizing hormone/chorionic gonadotrophin receptor overexpressed in granulosa cells from polycystic ovary syndrome ovaries is functionally active. Reproductive Biomedicine Online 32 635-641. (https://doi. org/10.1016/j.rbmo.2016.03.003)

Kokosar M, Benrick A, Perfilyev A, Fornes R, Nilsson E, Maliqueo M, Behre CJ, Sazonova A, Ohlsson C, Ling C et al. 2016 Epigenetic and transcriptional alterations in human adipose tissue of polycystic ovary syndrome. Scientific Reports 6 22883. (https://doi.org/10.1038/ srep22883)

Kokosar M, Benrick A, Perfilyev A, Nilsson E, Källman T, Ohlsson C, Ling C \& Stener-Victorin E 2018 A single bout of electroacupuncture remodels epigenetic and transcriptional changes in adipose tissue in polycystic ovary syndrome. Scientific Reports 8 1878. (https://doi.org/10.1038/ s41598-017-17919-5)

Korhonen S, Romppanen EL, Hiltunen M, Helisalmi S, Punnonen K, Hippeläinen M \& Heinonen S 2003 Two exonic single nucleotide polymorphisms in the microsomal epoxide hydrolase gene are associated with polycystic ovary syndrome. Fertility and Sterility 79 1353-1357. (https://doi.org/10.1016/S0015-0282(03)00385-6)

Lambertini L, Saul SR, Copperman AB, Hammerstad SS, Yi Z, Zhang W, Tomer Y \& Kase N 2017 Intrauterine reprogramming of the polycystic ovary syndrome: evidence from a pilot study of cord blood global methylation analysis. Frontiers in Endocrinology 8 352. (https://doi. org/10.3389/fendo.2017.00352)

Lan CW, Chen MJ, Tai KY, Yu DC, Yang YC, Jan PS, Yang YS, Chen HF \& Ho HN 2015 Functional microarray analysis of differentially expressed genes in granulosa cells from women with polycystic ovary syndrome related to MAPK/ERK signaling. Scientific Reports 5 14994. (https://doi. org/10.1038/srep14994)

Lei Y, Zhang X, Su J, Jeong M, Gundry MC, Huang YH, Zhou Y, Li W \& Goodell MA 2017 Targeted DNA methylation in vivo using an engineered dCas9-MQ1 fusion protein. Nature Communications 8 16026. (https:// doi.org/10.1038/ncomms16026)

Li M, Youngren JF, Dunaif A, Goldfine ID, Maddux BA, Zhang BB \& Evans JL 2002 Decreased insulin receptor (IR) autophosphorylation in fibroblasts from patients with PCOS: effects of serine kinase inhibitors and IR activators. Journal of Clinical Endocrinology and Metabolism 87 4088-4093. (https://doi.org/10.1210/jc.2002-020363)

Li S, Zhu D, Duan H, Ren A, Glintborg D, Andersen M, Skov V, Thomassen M, Kruse T \& Tan Q 2017 Differential DNA methylation patterns of polycystic ovarian syndrome in whole blood of Chinese women. Oncotarget 8 20656-20666. (https://doi.org/10.18632/ oncotarget.9327)

Li QN, Guo L, Hou Y, Ou XH, Liu Z \& Sun QY 2018 The DNA methylation profile of oocytes in mice with hyperinsulinaemia and hyperandrogenism as detected by single-cell level whole genome bisulphite sequencing (SC-WGBS) technology. Reproduction, Fertility, and Development $\mathbf{3 0}$ 1713-1719. (https://doi.org/10.1071/RD18002)

Liu YD, Li Y, Feng SX, Ye DS, Chen X, Zhou XY \& Chen SL 2017 Long noncoding RNAs: potential regulators involved in the pathogenesis of polycystic ovary syndrome. Endocrinology 158 3890-3899. (https://doi. org/10.1210/en.2017-00605)

Luense LJ, Veiga-Lopez A, Padmanabhan V \& Christenson LK 2011 Developmental programming: gestational testosterone treatment alters fetal ovarian gene expression. Endocrinology 152 4974-4983. (https:// doi.org/10.1210/en.2011-1182)

Manikkam M, Steckler TL, Welch KB, Inskeep EK \& Padmanabhan V 2006 Fetal programming: prenatal testosterone treatment leads to follicular persistence/luteal defects; partial restoration of ovarian function by cyclic progesterone treatment. Endocrinology 147 1997-2007. (https:// doi.org/10.1210/en.2005-1338)

Mannerås-Holm L, Leonhardt $\mathrm{H}$, Kullberg J, Jennische $\mathrm{E}$, Odén A, Holm G, Hellström M, Lönn L, Olivecrona G, Stener-Victorin E et al. 2011 Adipose tissue has aberrant morphology and function in PCOS: enlarged adipocytes and low serum adiponectin, but not circulating sex steroids, are strongly associated with insulin resistance. Journal of Clinical Endocrinology and Metabolism 96 E304-E311. (https://doi.org/10.1210/ jc.2010-1290)

Martínez-García MÁ, Montes-Nieto R, Fernández-Durán E, Insenser M, Luque-Ramírez M \& Escobar-Morreale HF 2013 Evidence for masculinization of adipokine gene expression in visceral and subcutaneous adipose tissue of obese women with polycystic ovary syndrome (PCOS). Journal of Clinical Endocrinology and Metabolism 98 E388-E396. (https://doi.org/10.1210/jc.2012-3414)

McCartney CR \& Marshall JC 2016 CLINICAL PRACTICE: Polycystic ovary syndrome. New England Journal of Medicine 375 54-64. (https://doi. org/10.1056/NEJMcp1514916)

Montes-Nieto R, Insenser M, Martínez-García MÁ \& Escobar-Morreale HF 2013 A nontargeted proteomic study of the influence of androgen excess on human visceral and subcutaneous adipose tissue proteomes. Journal of Clinical Endocrinology and Metabolism 98 E576-E585. (https://doi. org/10.1210/jc.2012-3438)

Mutharasan P, Galdones E, Peñalver Bernabé B, Garcia OA, Jafari N, Shea LD, Woodruff TK, Legro RS, Dunaif A \& Urbanek M 2013 Evidence 
for chromosome $2 \mathrm{p} 16.3$ polycystic ovary syndrome susceptibility locus in affected women of European ancestry. Journal of Clinical Endocrinology and Metabolism 98 E185-E190. (https://doi.org/10.1210/ jc.2012-2471)

Mykhalchenko K, Lizneva D, Trofimova T, Walker W, Suturina L, Diamond MP \& Azziz R 2017 Genetics of polycystic ovary syndrome. Expert Review of Molecular Diagnostics 17 723-733. (https://doi.org/10. 1080/14737159.2017.1340833)

Nebbioso A, Tambaro FP, Dell'Aversana C \& Altucci L 2018 Cancer epigenetics: moving forward. PLoS Genetics 14 e1007362. (https://doi. org/10.1371/journal.pgen.1007362)

Nelson-DeGrave VL, Wickenheisser JK, Cockrell JE, Wood JR, Legro RS, Strauss JF \& McAllister JM 2004 Valproate potentiates androgen biosynthesis in human ovarian theca cells. Endocrinology 145 799-808. (https://doi.org/10.1210/en.2003-0940)

Nestler JE, Jakubowicz DJ, de Vargas AF, Brik C, Quintero N \& Medina F 1998 Insulin stimulates testosterone biosynthesis by human thecal cells from women with polycystic ovary syndrome by activating its own receptor and using inositolglycan mediators as the signal transduction system. Journal of Clinical Endocrinology and Metabolism 83 2001-2005. (https://doi.org/10.1210/jcem.83.6.4886)

Neven ACH, Laven J, Teede HJ \& Boyle JA 2018 A summary on polycystic ovary syndrome: diagnostic criteria, prevalence, clinical manifestations, and management according to the latest international guidelines. Seminars in Reproductive Medicine 36 5-12. (https://doi. org/10.1055/s-0038-1668085)

Nilsson E, Benrick A, Kokosar M, Krook A, Lindgren E, Källman T, Martis MM, Højlund K, Ling C \& Stener-Victorin E 2018 Transcriptional and epigenetic changes influencing skeletal muscle metabolism in women With polycystic ovary syndrome. Journal of Clinical Endocrinology and Metabolism 103 4465-4477. (https://doi.org/10.1210/jc.2018-00935)

O'Reilly M, Gathercole L, Capper F, Arlt W \& Tomlinson J 2015 Effect of insulin on AKR1C3 expression in female adipose tissue: in-vivo and invitro study of adipose androgen generation in polycystic ovary syndrome. Lancet 385 S16. (https://doi.org/10.1016/S0140-6736(15)60331-2)

Orio F, Palomba S, Cascella T, Di Biase S, Manguso F, Tauchmanovà L, Nardo LG, Labella D, Savastano S, Russo T et al. 2005 The increase of leukocytes as a new putative marker of low-grade chronic inflammation and early cardiovascular risk in polycystic ovary syndrome. Journal of Clinical Endocrinology and Metabolism 90 2-5. (https://doi.org/10.1210/ jc.2004-0628)

Ortega HH, Rey F, Velazquez MML \& Padmanabhan V 2010 Developmental programming: effect of prenatal steroid excess on intraovarian components of insulin signaling pathway and related proteins in sheep. Biology of Reproduction 82 1065-1075. (https://doi. org/10.1095/biolreprod.109.082719)

Padmanabhan V \& Veiga-Lopez A 2013 Sheep models of polycystic ovary syndrome phenotype. Molecular and Cellular Endocrinology 373 8-20. (https://doi.org/10.1016/j.mce.2012.10.005)

Padmanabhan V, Salvetti NR, Matiller V \& Ortega HH 2014 Developmental programming: prenatal steroid excess disrupts key members of intraovarian steroidogenic pathway in sheep. Endocrinology 155 3649-3660. (https://doi.org/10.1210/en.2014-1266)

Pan JX, Tan YJ, Wang FF, Hou NN, Xiang YQ, Zhang JY, Liu Y, Qu F, Meng Q, Xu J et al. 2018 Aberrant expression and DNA methylation of lipid metabolism genes in PCOS: a new insight into its pathogenesis. Clinical Epigenetics 10 6. (https://doi.org/10.1186/s13148-018-0442-y)

Patel S 2018 Polycystic ovary syndrome (PCOS), an inflammatory, systemic, lifestyle endocrinopathy. Journal of Steroid Biochemistry and Molecular Biology 182 27-36. (https://doi.org/10.1016/j.jsbmb.2018.04.008)

Pellatt L, Hanna L, Brincat M, Galea R, Brain H, Whitehead S \& Mason H 2007 Granulosa cell production of anti-Müllerian hormone is increased in polycystic ovaries. Journal of Clinical Endocrinology and Metabolism 92 240-245. (https://doi.org/10.1210/jc.2006-1582)

Piltonen TT 2016 Polycystic ovary syndrome: endometrial markers. Best Practice and Research: Clinical Obstetrics and Gynaecology 37 66-79. (https://doi.org/10.1016/j.bpobgyn.2016.03.008)

Pruksananonda K, Wasinarom A, Sereepapong W, Sirayapiwat P, Rattanatanyong P \& Mutirangura A 2016 Epigenetic modification of long interspersed elements- 1 in cumulus cells of mature and immature oocytes from patients with polycystic ovary syndrome. Clinical and
Experimental Reproductive Medicine 43 82-89. (https://doi.org/10.5653/ cerm.2016.43.2.82)

Puttabyatappa M, Irwin A, Martin JD, Mesquitta M, Veiga-Lopez A \& Padmanabhan V 2018 Developmental programming: gestational exposure to excess testosterone alters expression of ovarian matrix metalloproteases and their target proteins. Reproductive Sciences 25 882-892. (https://doi.org/10.1177/1933719117697127)

Qu F, Wang F-F, Yin R, Ding G-L, El-Prince M, Gao Q, Shi B-W, Pan H-H, Huang Y-T, Jin M et al. 2012 A molecular mechanism underlying ovarian dysfunction of polycystic ovary syndrome: hyperandrogenism induces epigenetic alterations in the granulosa cells. Journal of Molecular Medicine 90 911-923. (https://doi.org/10.1007/s00109-012-0881-4)

Rae M, Grace C, Hogg K, Wilson LM, McHaffie SL, Ramaswamy S, MacCallum J, Connolly F, McNeilly AS \& Duncan C 2013 The pancreas is altered by in utero androgen exposure: implications for clinical conditions such as polycystic ovary syndrome (PCOS). PLOS ONE 8 e56263. (https://doi.org/10.1371/journal.pone.0056263)

Ramaswamy S, Grace C, Mattei AA, Siemienowicz K, Brownlee W, MacCallum J, McNeilly AS, Duncan WC \& Rae MT 2016 Developmental programming of polycystic ovary syndrome (PCOS): prenatal androgens establish pancreatic islet $\alpha / \beta$ cell ratio and subsequent insulin secretion. Scientific Reports 6 27408. (https://doi.org/10.1038/srep27408)

Reimand J, Arak T, Adler P, Kolberg L, Reisberg S, Peterson H \& Vilo J 2016 g:profiler - a web server for functional interpretation of gene lists (2016 update). Nucleic Acids Research 44 W83-W89. (https://doi. org/10.1093/nar/gkw199)

Reyes-Muñoz E, Ortega-González C, Martínez-Cruz N, Arce-Sánchez L, Estrada-Gutierrez G, Moran C, Sánchez-Serrano AP, HigaredaSánchez R \& de la Jara-Díaz JF 2016 Association of obesity and overweight with the prevalence of insulin resistance, pre-diabetes and clinical-biochemical characteristics among infertile Mexican women with polycystic ovary syndrome: a cross-sectional study. BMJ Open 6 e012107. (https://doi.org/10.1136/bmjopen-2016-012107)

Rosa-Garrido M, Chapski DJ \& Vondriska TM 2018 Epigenomes in cardiovascular disease. Circulation Research 122 1586-1607. (https:// doi.org/10.1161/CIRCRESAHA.118.311597)

Sagvekar P, Mangoli V, Desai S, Patil A \& Mukherjee S 2017 LINE1 CpGDNA hypomethylation in granulosa cells and blood leukocytes is associated With PCOS and related traits. Journal of Clinical Endocrinology and Metabolism 102 1396-1405. (https://doi.org/10.1210/jc.2016-2645)

Sagvekar P, Dadachanji R, Patil K \& Mukherjee S 2018 Pathomechanisms of polycystic ovary syndrome: multidimensional approaches. Frontiers in Bioscience 10 384-422. (https://doi.org/10.2741/829)

Salehi Jahromi M, Hill JW, Ramezani Tehrani F \& Zadeh-Vakili A 2018 Hypomethylation of specific CpG sites in the promoter region of steroidogeneic genes (GATA6 and StAR) in prenatally androgenized rats. Life Sciences 207 105-109. (https://doi.org/10.1016/j.Ifs.2018.05.052)

Sang Q, Zhang S, Zou S, Wang H, Feng R, Li Q, Jin L, He L, Xing Q \& Wang L 2013 Quantitative analysis of follistatin (FST) promoter methylation in peripheral blood of patients with polycystic ovary syndrome. Reproductive Biomedicine Online 26 157-163. (https://doi. org/10.1016/j.rbmo.2012.10.011)

Sang Q, Li X, Wang H, Wang H, Zhang S, Feng R, Xu Y, Li Q, Zhao X, Xing Q et al. 2014 Quantitative methylation level of the EPHX1 promoter in peripheral blood DNA is associated with polycystic ovary syndrome. PLOS ONE 9 e88013. (https://doi.org/10.1371/journal.pone.0088013)

Senner CE 2011 The role of DNA methylation in mammalian development. Reproductive Biomedicine Online 22 529-535. (https://doi. org/10.1016/j.rbmo.2011.02.016)

Seto-Young D, Paliou M, Schlosser J, Avtanski D, Park A, Patel P, Holcomb K, Chang P \& Poretsky L 2005 Direct thiazolidinedione action in the human ovary: insulin-independent and insulin-sensitizing effects on steroidogenesis and insulin-like growth factor binding Protein-1 production. Journal of Clinical Endocrinology and Metabolism 90 6099-6105. (https://doi.org/10.1210/jc.2005-0469)

Seto-Young D, Avtanski D, Strizhevsky M, Parikh G, Patel P, Kaplun J, Holcomb K, Rosenwaks Z \& Poretsky L 2007 Interactions among peroxisome proliferator activated receptor- $\gamma$, insulin signaling pathways, and steroidogenic acute regulatory protein in human ovarian cells. Journal of Clinical Endocrinology and Metabolism 92 2232-2239. (https://doi.org/10.1210/jc.2006-1935) 
Shen HR, Qiu LH, Zhang ZQ, Qin YY, Cao C \& Di W 2013 Genomewide methylated DNA immunoprecipitation analysis of patients with polycystic ovary syndrome. PLOS ONE 8 e64801. (https://doi. org/10.1371/journal.pone.0064801)

Shi Y, Zhao H, Shi Y, Cao Y, Yang D, Li Z, Zhang B, Liang X, Li T, Chen J et al. 2012 Genome-wide association study identifies eight new risk loci for polycystic ovary syndrome. Nature Genetics 44 1020-1025. (https:// doi.org/10.1038/ng.2384)

Shorakae S, Ranasinha S, Abell S, Lambert G, Lambert E, de Courten B \& Teede H 2018 Inter-related effects of insulin resistance, hyperandrogenism, sympathetic dysfunction and chronic inflammation in PCOS. Clinical Endocrinology 89 628-633. (https://doi.org/10.1111/ cen.13808)

Silva Dantas W, Gualano B, Patrocínio Rocha M, Roberto Grimaldi Barcellos C, dos Reis Vieira Yance V \& Miguel Marcondes JA 2013 Metabolic disturbance in PCOS: clinical and molecular effects on skeletal muscle tissue. Scientific World Journal 2013 1-7. (https://doi. org/10.1155/2013/178364)

Silva MSB, Prescott M \& Campbell RE 2018 Ontogeny and reversal of brain circuit abnormalities in a preclinical model of PCOS. JCI Insight 3 99405. (https://doi.org/10.1172/jci.insight.99405)

Sirmans SM \& Pate KA 2013 Epidemiology, diagnosis, and management of polycystic ovary syndrome. Clinical Epidemiology 6 1-13. (https://doi. org/10.2147/CLEP.S37559)

Skov V, Glintborg D, Knudsen S, Jensen T, Kruse TA, Tan Q, Brusgaard K, Beck-Nielsen H \& Hojlund K 2007 Reduced expression of nuclearencoded genes involved in mitochondrial oxidative metabolism in skeletal muscle of insulin-resistant women With polycystic ovary syndrome. Diabetes 56 2349-2355. (https://doi.org/10.2337/db070275)

Smith P, Steckler TL, Veiga-Lopez A \& Padmanabhan V 2009 Developmental programming: differential effects of prenatal testosterone and dihydrotestosterone on follicular recruitment, depletion of follicular reserve, and ovarian morphology in sheep. Biology of Reproduction $\mathbf{8 0}$ 726-736. (https://doi.org/10.1095/biolreprod.108.072801)

Smyka M, Grzechocinska B \& Wielgos M 2018 The role of lifestyle changes in the treatment of polycystic ovary syndrome. Neuro Endocrinology Letters 38 521-527.

Solovei I, Wang AS, Thanisch K, Schmidt CS, Krebs S, Zwerger M, Cohen TV, Devys D, Foisner R, Peichl L et al. 2013 LBR and lamin A/C sequentially tether peripheral heterochromatin and inversely regulate differentiation. Cell 152 584-598. (https://doi.org/10.1016/j.cell.2013.01.009)

Sørensen AE, Udesen PB, Wissing ML, Englund ALM \& Dalgaard LT 2016 MicroRNAs related to androgen metabolism and polycystic ovary syndrome. Chemico-Biological Interactions 259 8-16. (https://doi. org/10.1016/j.cbi.2016.06.008)

Stener-Victorin E 2013 Hypothetical physiological and molecular basis for the effect of acupuncture in the treatment of polycystic ovary syndrome. Molecular and Cellular Endocrinology 373 83-90. (https:// doi.org/10.1016/j.mce.2013.01.006)

Stocco C 2012 Tissue physiology and pathology of aromatase. Steroids 77 27-35. (https://doi.org/10.1016/j.steroids.2011.10.013)

Tata B, Mimouni NEH, Barbotin AL, Malone SA, Loyens A, Pigny P, Dewailly D, Catteau-Jonard S, Sundström-Poromaa I, Piltonen TT et al. 2018 Elevated prenatal anti-Müllerian hormone reprograms the fetus and induces polycystic ovary syndrome in adulthood. Nature Medicine 24 834-846. (https://doi.org/10.1038/s41591-018-0035-5)

Teede H, Deeks A \& Moran L 2010 Polycystic ovary syndrome: a complex condition with psychological, reproductive and metabolic manifestations that impacts on health across the lifespan. BMC Medicine 8 41. (https:// doi.org/10.1186/1741-7015-8-41)

Teede HJ, Misso ML, Costello MF, Dokras A, Laven J, Moran L, Piltonen T, Norman RJ \& International PCOS Network 2018 Recommendations from the international evidence-based guideline for the assessment and management of polycystic ovary syndrome. Fertility and Sterility $\mathbf{1 1 0}$ 364-379. (https://doi.org/10.1016/j.fertnstert.2018.05.004)

Thessaloniki ESHRE/ASRM-Sponsored PCOS Consensus Workshop Group 2008 Consensus on infertility treatment related to polycystic ovary syndrome. Human Reproduction 23 462-477. (https://doi.org/10.1093/ humrep/dem426)
Ting W, Yanyan Q, Jian H, Keqin H \& Duan M 2013 The relationship between insulin resistance and CpG island methylation of LMNA gene in polycystic ovary syndrome. Cell Biochemistry and Biophysics 67 1041-1047. (https://doi.org/10.1007/s12013-013-9602-z)

Titus AJ, Gallimore RM, Salas LA \& Christensen BC 2017 Cell-type deconvolution from DNA methylation: a review of recent applications. Human Molecular Genetics 26 R216-R224. (https://doi.org/10.1093/ $\mathrm{hmg} / \mathrm{ddx} 275$ )

Toth B, Hornung D, Scholz C, Djalali S, Friese K \& Jeschke U 2007 Peroxisome proliferator-activated receptors: new players in the field of reproduction. American Journal of Reproductive Immunology $\mathbf{5 8}$ 289-310. (https://doi.org/10.1111/j.1600-0897.2007.00514.x)

Trikudanathan S 2015 Polycystic ovarian syndrome. Medical Clinics of North America 99 221-235. (https://doi.org/10.1016/j.mcna.2014.09.003)

Vandenbeek R, Khan NP \& Estall JL 2018 Linking metabolic disease with the PGC-1 $\alpha$ Gly482Ser polymorphism. Endocrinology 159 853-865. (https://doi.org/10.1210/en.2017-00872)

Veiga-Lopez A, Ye W, Phillips DJ, Herkimer C, Knight PG \& Padmanabhan V 2008 Developmental programming: deficits in reproductive hormone dynamics and ovulatory outcomes in prenatal, testosterone-treated sheep. Biology of Reproduction 78 636-647. (https://doi.org/10.1095/ biolreprod.107.065904)

Veiga-Lopez A, Ye W \& Padmanabhan V 2012 Developmental programming: prenatal testosterone excess disrupts anti-Müllerian hormone expression in preantral and antral follicles. Fertility and Sterility 97 748-756. (https://doi.org/10.1016/j.fertnstert.2011.12.028)

Wang P, Zhao H, Li T, Zhang W, Wu K, Li M, Bian Y, Liu H, Ning Y, Li G et al. 2014a Hypomethylation of the $\mathrm{LH} /$ choriogonadotropin receptor promoter region is a potential mechanism underlying susceptibility to polycystic ovary syndrome. Endocrinology 155 1445-1452. (https://doi. org/10.1210/en.2013-1764)

Wang XX, Wei JZ, Jiao J, Jiang SY, Yu DH \& Li D 2014b Genome-wide DNA methylation and gene expression patterns provide insight into polycystic ovary syndrome development. Oncotarget 5 6603-6610. (https://doi.org/10.18632/oncotarget.2224)

Wood JR, Nelson-Degrave VL, Jansen E, McAllister JM, Mosselman S \& Strauss JF 2005 Valproate-induced alterations in human theca cell gene expression: clues to the association between valproate use and metabolic side effects. Physiological Genomics 20 233-243. (https://doi. org/10.1152/physiolgenomics.00193.2004)

Xu N, Azziz R \& Goodarzi MO 2010 Epigenetics in polycystic ovary syndrome: a pilot study of global DNA methylation. Fertility and Sterility 94 781.e1-783.e1. (https://doi.org/10.1016/j. fertnstert.2009.10.020)

Xu N, Kwon S, Abbott DH, Geller DH, Dumesic DA, Azziz R, Guo X \& Goodarzi MO 2011 Epigenetic mechanism underlying the development of polycystic ovary syndrome (PCOS)-like phenotypes in prenatally androgenized rhesus monkeys. PLOS ONE 6 e27286. (https://doi. org/10.1371/journal.pone.0027286)

Xu J, Bao X, Peng Z, Wang L, Du L, Niu W \& Sun Y 2016 Comprehensive analysis of genome-wide DNA methylation across human polycystic ovary syndrome ovary granulosa cell. Oncotarget 7 27899-27909. (https://doi.org/10.18632/oncotarget.8544)

Yamamoto H, Kurebayashi S, Hirose T, Kouhara H \& Kasayama S 2002 Reduced IRS-2 and GLUT4 expression in PPARgamma2-induced adipocytes derived from C/EBPbeta and C/EBPdelta-deficient mouse embryonic fibroblasts. Journal of Cell Science 115 3601-3607. (https:// doi.org/10.1242/jcs.00044)

Yang F, Ruan YC, Yang YJ, Wang K, Liang SS, Han YB, Teng XM \& Yang JZ 2015 Follicular hyperandrogenism downregulates aromatase in luteinized granulosa cells in polycystic ovary syndrome women. Reproduction 150 289-296. (https://doi.org/10.1530/REP-15-0044)

Yu YY, Sun CX, Liu YK, Li Y, Wang L \& Zhang W 2013 Promoter methylation of CYP19A1 gene in Chinese polycystic ovary syndrome patients. Gynecologic and Obstetric Investigation 76 209-213. (https:// doi.org/10.1159/000355314)

Yu YY, Sun CX, Liu YK, Li Y, Wang L \& Zhang W 2015 Genome-wide screen of ovary-specific DNA methylation in polycystic ovary syndrome. Fertility and Sterility 104 145.e6-153.e6. (https://doi.org/10.1016/j. fertnstert.2015.04.005) 
Zhang D, Cong J, Shen H, Wu Q \& Wu X 2014 Genome-wide identification of aberrantly methylated promoters in ovarian tissue of prenatally androgenized rats. Fertility and Sterility 102 1458-1467. (https://doi. org/10.1016/j.fertnstert.2014.07.1203)

Zhao H, Zhao Y, Ren Y, Li M, Li T, Li R, Yu Y \& Qiao J 2017 Epigenetic regulation of an adverse metabolic phenotype in polycystic ovary syndrome: the impact of the leukocyte methylation of PPARGC1A promoter. Fertility and Sterility 107 467-474.e5. (https://doi. org/10.1016/j.fertnstert.2016.10.039)

Zhong T, Men Y, Lu L, Geng T, Zhou J, Mitsuhashi A, Shozu M, Maihle NJ, Carmichael GG, Taylor HS et al. 2017 Metformin alters DNA methylation genome-wide via the H19/SAHH axis. Oncogene 36 2345-2354. (https://doi.org/10.1038/onc.2016.391)
Zhou Z, Sun B, Li X \& Zhu C 2018 DNA methylation landscapes in the pathogenesis of type 2 diabetes mellitus. Nutrition and Metabolism 15 47. (https://doi.org/10.1186/s12986-018-0283-x)

Received 24 August 2018

First decision 27 September 2018

Revised manuscript received 29 March 2019

Accepted 8 April 2019 